\title{
The chemical composition of oyster nut (Telfairia pedata) seeds and oil ${ }^{\text {th }}$
}

\author{
Paolo Bondioli ${ }^{1, *}$, Liliana Folegatti ${ }^{2}$ and Gabriella Morini ${ }^{3}$ \\ ${ }^{1}$ Freelance Expert, Milano, Italy \\ 2 INNOVHUB-SSI-SSOG, Milano, Italy \\ ${ }^{3}$ University of Gastronomic Sciences, Pollenzo, Italy
}

Received 1 September 2020 - Accepted 23 November 2020

\begin{abstract}
In this paper, the chemical composition of Telfairia pedata seeds and oil is discussed. This crop belongs to the family of Cucurbitaceae. Unroasted seeds and oil obtained from roasted seeds were collected during a study trip in Tanzania. Oil from unroasted seeds was extracted in the lab using hexane. The seeds contain approximately $60(\% \mathrm{~m} / \mathrm{m})$ of oil and $30(\% \mathrm{~m} / \mathrm{m})$ of protein, being the remaining amount represented by crude fiber, carbohydrates and mineral constituents. The protein fraction contains glutamic acid, arginine, aspartic acid and leucine as the most representative amino acids. The fatty acid composition is a common one, being palmitic, linoleic, stearic and oleic acids, the most important fatty acids detected. No difference was found in fatty acid composition between oils extracted from roasted and unroasted seeds. On the contrary, the oil obtained from roasted seeds shows a higher concentration in sterols and tocopherols while the distribution between the different constituents remains the same.
\end{abstract}

Keywords: Telfairia pedata / oyster nut / seed composition / oil composition / roasting

Résumé - La composition chimique des graines et de l'huile de Kouémé (Telfairia pedata). Cet article traite de la composition chimique des graines et de l'huile de Telfairia pedata. Cette plante appartient à la famille des cucurbitacées. Les graines non torréfiées et l'huile obtenue à partir de graines torréfiées ont été recueillies au cours d'un voyage d'étude en Tanzanie. L'huile des graines non torréfiées a été extraite en laboratoire à l'aide d'hexane. Les graines contiennent environ $60(\% \mathrm{~m} / \mathrm{m})$ d'huile et $30(\% \mathrm{~m} / \mathrm{m})$ de protéines, le reste étant représenté par des fibres brutes, des hydrates de carbone et des constituants minéraux. Les acides aminés les plus représentés de la fraction protéique sont l'acide glutamique, l'arginine, l'acide aspartique et la leucine. La composition en acides gras est commune, les acides palmitique, linoléique, stéarique et oléique étant les acides gras les plus importants détectés. Aucune différence n'a été constatée dans la composition des acides gras entre les huiles extraites de graines torréfiées et non torréfiées. Au contraire, l'huile obtenue à partir de graines torréfiées présente une concentration plus élevée en stérols et tocophérols, alors que la répartition entre les différents constituants reste la même.

Mots clés : Telfairia pedata / Kouémé / composition des graines / composition de l'huile / torréfaction

\section{Introduction}

Looking at the vegetable kingdom, a huge number of uncommon oil crops can be found: this time, we shall discuss about the chemical composition of seeds and oils of Telfairia pedata, commonly known as oyster nut, because of the particular shape of its seeds. It is also known as Queen's nut, Zanzibar oil vine Kouémé, Bane, Châtaigne de l'Inhambane, Liane de Joliff and is a dioecious African liana which can grow up to $30 \mathrm{~m}$ long, having purple-pink fringed flowers, and very large (30-90 cm $\times 15-25 \mathrm{~cm})$, many-seeded, drooping, ellipsoid berries which can weigh up to $15 \mathrm{~kg}$ (Kanyua, 2016). According to the information found from different sources Telfairia pedata belongs to the family of Curcubitaceae. It can be found in Tanzania, Isles of Zanzibar, Pemba and Mozambique and is cultivated in Central, East and Southern Africa from Rwanda and Uganda to Ethiopia and southwards through Tanzania to Zambia, Malawi, Mozambique and South

\footnotetext{
Contribution to the Topical Issue "Minor oils from atypical plant sources / Huiles mineures de sources végétales atypiques".

*Correspondence: paolo.bondioli1956@gmail.com
} 
Africa. It has been grown in Madagascar and Mauritius, but there its importance has declined (PROTA4U database, web source).

Telfairia pedata is an oil nut plant found in lowland coastal and river line forests at elevations of up to $1100 \mathrm{~m}$, in areas with mean annual rainfall of $1000 \mathrm{~mm}$ or $2000 \mathrm{~mm}$. Telfairia pedata is a perennial plant that does not suffer seasonal climatic changes and is drought resistant, with low susceptibility to disease and pest attack. Apart from grasshoppers and termites, there are few pests and diseases, which infest the plant. After three years, it produces 10 to 30 fruits and each fruit contains 70 to 150 seeds. In Tanzania, a good plantation can reach an annual seed yield of 3 to 7 tons per hectare. The oil is generally extracted from the seeds using presses and after extraction the press cake represents a valuable feed for livestock, thanks to the high protein content. As it can represent an interesting source of oil material and proteins, we decided to evaluate in detail this seed, the oil obtained by means of hexane extraction of the seed and a sample of oil extracted from roasted seeds coming from an African street market where it is sold as a common product.

The seed is sometimes in use to replace almonds or brazil nuts in confectionery. It is irregularly circular in shape, about $4 \mathrm{~cm}$ in diameter and $12 \mathrm{~mm}$ thick. The seed contains a bitter principle that can be removed by soaking in water for some hours.

\section{Material and methods}

\subsection{Materials}

The seeds with hull were obtained from a student travelling through Tanzania during year 2019. The oil from roasted seeds was purchased in a street market in the city of Morogoro (Tanzania) during the same trip.

Pictures of seeds and berries can be easily found in the web. All studies were carried out using the dehulled seed. The hull represents approximately $30 \%$ of the whole seed.

\subsection{Analytical methods - Seed}

\subsubsection{Humidity and volatile matter:}

This property was evaluated by means of weight loss in thermostatic oven set at $103^{\circ} \mathrm{C}$, using ISO 665:2000 standard.

\subsubsection{Protein content}

The evaluation was carried out using the classic Kjieldahl procedure and protein content was calculated after determination of total nitrogen content $(\mathrm{N} \times 6.25)$ according to ISO 5983-1:2005 standard.

\subsubsection{Oil content}

A classic Soxhlet extraction using hexane, according to UNI EN ISO 659:2009 was used.

\subsubsection{Crude fiber}

The sample is subjected in sequence to acid and alkaline treatment. The obtained residue, dried and weighed, is then incinerated. Weight loss after incineration and ash deduction represents the raw fiber content. Reference method: UNI 22606:1992.

\subsubsection{Ash content}

The sample is subjected to combustion and subsequent incineration at $550{ }^{\circ} \mathrm{C}$. At the end of the procedure, the resulting ashes are evaluated gravimetrically. Reference method: UNI 22602:1992.

\subsubsection{Amino acid composition}

Sample preparation (UNI 22614:1992): the sample is hydrolyzed by means of hot treatment with $6 \mathrm{M} \mathrm{HCl}$ containing $0.1 \%$ phenol were added at $110^{\circ} \mathrm{C}$ for 24 hours. Sample analysis (UNI 22615:1992): the amino acid of the sample, prepared after acidic hydrolysis are separated and quantified in an amino analyzer instrument (Aminoanalyzer Biochrom Bio30+, Erreci, Milan, Italy) by means of ionic chromatography and ninhydrin colorimetric detection.

The amino acids were separated by elution on a cation exchange resin column (high pressure PEEK column packed with Ultropac 8 cation exchange resin; column length: $200 \mathrm{~mm}$; column diameter: $4.5 \mathrm{~mm}$; temperature: $25^{\circ} \mathrm{C}$; flow rate: $25 \mathrm{~mL} / \mathrm{h}$ ) and detected at $570 \mathrm{~nm}$ after post-column derivatization with Ninhydrin (flow rate: $20 \mathrm{~mL} / \mathrm{h}$; reaction temperature: $135^{\circ} \mathrm{C}$ ). The chromatograms were acquired and processed with the Clarity - Chromatography 7.1 software. The amino acid concentration was determined by external calibration using a standard mixture of amino acids (Sigma, cod. AA-S-18). The results were expressed in $\mathrm{g} / 100 \mathrm{~g}$ sample.

\subsubsection{Tryptophan content}

The amino acid was analyzed by means of the same amino analyzer after basic hydrolysis, according to method UNI 22618:2000 + UNI 22620:2000.

\subsubsection{Sulphated amino acids}

Sulphated amino acids (cysteine and methionine) were analyzed by means of the same amino analyzer carrying out an oxidation at $0{ }^{\circ} \mathrm{C}$ with a performic acid/phenol mixture before to acidic hydrolysis, according to method UNI 22619:2000+ UNI 22621:2000. Cyst(e)ine and methionine must be oxidized to cysteic acid and methionine sulphone respectively, prior to hydrolysis.

\subsection{Analytical methods - Oil}

All reported analytical methods are discussed in detail by Bondioli et al. (2020):

- acidity and total acid number (T.A.N.): UNI EN ISO 660:2009 method;

- fatty acid composition: ISO 12966-2:2017+ ISO 12966-4:2015;

- sterol content and composition NGD 71:1989+ NGD 72:1989;

- tocopherol content and distribution: ISO 9936:2016. 


\section{Results and discussion}

The gross composition of the dehulled seed is reported in Table 1 . The evaluated seeds contain a very high amount of crude lipids, more than $60 \%$ and an interesting amount of protein that becomes more and more concentrated on the defatted meal, with the possibility to reach a concentration higher than $70 \%$. As usual we also analyzed the cake to evaluate the amino acid composition that is contained in Table 2. Sulphur-containing amino acids (methionine and cysteine) were separately evaluated as well as tryptophan. From the reported data, we can say that this seed represents a very interesting source of vegetable proteins for food and feed production. A literature review did not evidence the presence of antinutritional factors in seeds.

After the evaluation of seed composition, we turned our interest to the oil sample obtained by hexane extraction of dehulled seed and on the oil sample from the market, obtained

Table 1. Chemical composition of dehulled Telfairia pedata seed.

\begin{tabular}{lr}
\hline Moisture, \% & $3.09 \pm 0.93$ \\
Crude fat, \% & $61.20 \pm 1.21$ \\
Protein $(\mathrm{N} \times 6.25), \%$ & $29.08 \pm 1.43$ \\
Crude fiber, \% & $1.00 \pm 0.13$ \\
Ashes, \% & $2.57 \pm 0.04$ \\
Carbohydrates, \% (by difference to 100) & 3.06 \\
\hline
\end{tabular}

Results represent the average value of two independent analyses \pm uncertainty of measurement $(95 \%)$. from the roasted seeds. The two samples are different in color (one is yellow, the other is dark), in flavor and in viscosity.

As expected, the fatty acid composition (Tab. 3) did not show any significant difference. Differences of approximate$1 y \pm 1 \%$ in relative concentration can be attributed to the different seeds used for preparation.

Among the saturated fatty acids that in total reach approximately $45 \%$, palmitic and stearic acids are in high quantity (31 and 13\% respectively), while unsaturated fatty acids are represented mainly by linoleic (44\%) and oleic (less than $10 \%$ ). The linolenic acid was detected only in very low concentration. Just as a remark the occurrence of eicosatetraenoic acid (C20:4) was detected. The presence of eicosatetraenoic acid in Telfairia pedata oil was already reported in a previous paper (Minzangi et al., 2015). Also, the sterol composition does not show important differences between the two samples (Tab. 4).

The most abundant sterols are beta-Sitosterol and delta 7Stigmastenol in similar concentrations; all other common sterols are represented in the samples. It is interesting to underline that, on the contrary, the total sterol content shows huge differences. In particular, the sterol content of oil obtained from the roasted seed is double than the one from unroasted seed. The same effect can be seen on tocopherol content (Tab. 5), where the oil from the roasted seed contains a total amount of $692.2 \mathrm{mg} / \mathrm{kg}$ versus $565.1 \mathrm{mg} / \mathrm{kg}$ of the oil from untreated seed. Gamma tocopherol represents more the $98 \%$ of total tocopherol content. The higher content in oils from roasted seeds does not represent an uncommon fact: in a recent paper on walnut oil (Gao et al., 2019) Authors underlined the same difference.

According to the author's interpretation the applied heat breaks the bonds, which link tocopherols to proteins, or

Table 2. Amino acid composition of Telfairia pedata proteins in the seed.

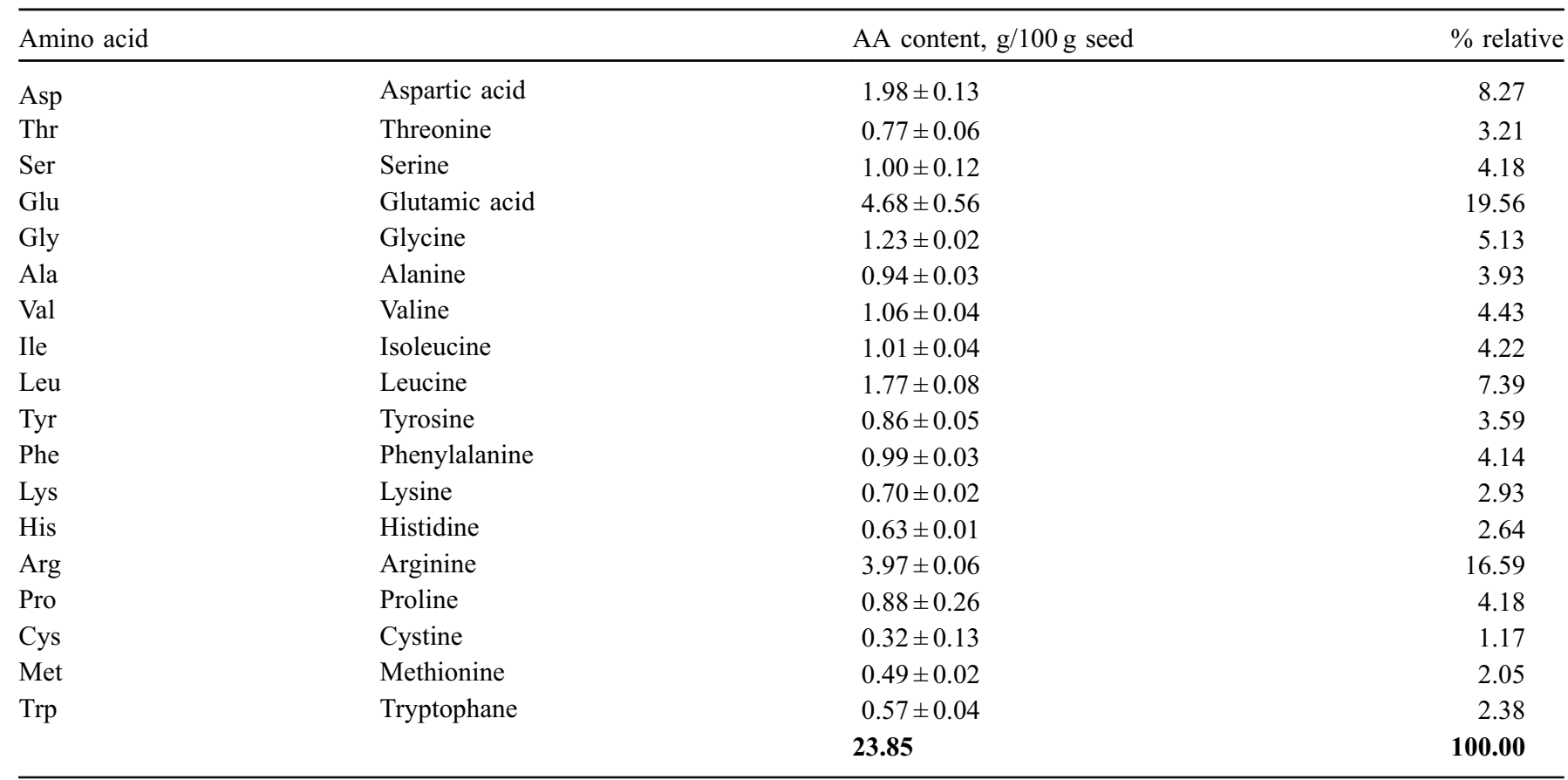

Results represent the average value of two independent analyses \pm uncertainty of measurement $(95 \%)$. 
Table 3. Fatty acid composition of oil obtained from the Telfairia pedata seeds.

\begin{tabular}{lrrr}
\hline Fatty acid, \% relative & & Oil from unroasted seed & Oil from roasted seed \\
\hline Myristic & $\mathrm{C}_{14: 0}$ & $0.08 \pm 0.01$ & $0.08 \pm 0.01$ \\
Palmitic & $\mathrm{C}_{16: 0}$ & $31.95 \pm 2.38$ & $30.35 \pm 2.38$ \\
Palmitoleic & $\mathrm{C}_{16: 1}$ & $0.21 \pm 0.02$ & $0.19 \pm 0.02$ \\
Heptadecanoic & $\mathrm{C}_{17: 0}$ & $0.08 \pm 0.01$ & $0.08 \pm 0.01$ \\
Heptadecenoic & $\mathrm{C}_{17: 1}$ & $0.01 \pm 0.03$ & $0.02 \pm 0.03$ \\
Stearic & $\mathrm{C}_{18: 0}$ & $12.45 \pm 1.06$ & $13.81 \pm 1.06$ \\
Oleic & $\mathrm{C}_{18: 1}$ & $9.61 \pm 0.14$ & $9.45 \pm 0.14$ \\
Linoleic & $\mathrm{C}_{18: 2}$ & $44.63 \pm 2.41$ & $44.88 \pm 2.41$ \\
Linolenic & $\mathrm{C}_{18: 3}$ & $0.01 \pm 0.02$ & $0.05 \pm 0.02$ \\
Arachidic & $\mathrm{C}_{20: 0}$ & $0.56 \pm 0.03$ & $0.58 \pm 0.03$ \\
Eicosenoic & $\mathrm{C}_{20: 1}$ & $0.03 \pm 0.03$ & $0.04 \pm 0.03$ \\
Eicosatetraenoic & $\mathrm{C}_{20: 4}$ & $0.17 \pm 0.40$ & $0.17 \pm 0.40$ \\
Behenic & $\mathrm{C}_{22: 0}$ & $0.12 \pm 0.02$ & $0.12 \pm 0.02$ \\
Lignoceric & $\mathrm{C}_{24: 0}$ & $0.08 \pm 0.08$ & $0.09 \pm 0.08$ \\
Tetracosenoic & $\mathrm{C}_{24: 1}$ & $0.01 \pm 0.08$ & $0.09 \pm 0.08$ \\
\hline
\end{tabular}

Results represent the average value of two independent analyses \pm uncertainty of measurement $(95 \%)$.

Table 4. Sterol composition of oil obtained from the two samples of Telfairia pedata seeds.

\begin{tabular}{lcr}
\hline Sterol, \% relative & $\begin{array}{l}\text { Oil from } \\
\text { unroasted seed }\end{array}$ & $\begin{array}{l}\text { Oil from } \\
\text { roasted seed }\end{array}$ \\
\hline Cholesterol & $1.16 \pm 0.12$ & $0.20 \pm 0.12$ \\
Brassicasterol & - & $0.17 \pm 0.09$ \\
24-Methylenecholesterol & $0.19 \pm 0.06$ & $0.20 \pm 0.06$ \\
Campesterol & $2.59 \pm 0.65$ & $2.36 \pm 0.65$ \\
Campestanol & $0.47 \pm 0.10$ & $0.30 \pm 0.10$ \\
Stigmasterol & $4.36 \pm 0.34$ & $4.50 \pm 0.34$ \\
Delta 7-Campesterol & - & $1.23 \pm 0.11$ \\
Clerosterol & $2.03 \pm 0.29$ & $2.01 \pm 0.29$ \\
Beta-sitosterol & $31.47 \pm 2.84$ & $28.21 \pm 2.84$ \\
Sitostanol & $8.36 \pm 0.94$ & $8.81 \pm 0.94$ \\
Delta 5-Avenasterol & $8.57 \pm 1.32$ & $9.39 \pm 1.32$ \\
Delta 7 (9.11)-Stigmastadienol & - & $0.86 \pm \mathrm{n} . \mathrm{d}$. \\
Delta 5.24-Stigmastadienol & $6.68 \pm 0.75$ & $6.12 \pm 0.75$ \\
Delta 7-Stigmastenol & $23.12 \pm 0.32$ & $23.93 \pm 0.32$ \\
Delta 7-Aavenasterol & $11.00 \pm 0.47$ & $11.71 \pm 0.47$ \\
Total sterol content, mg/kg & $1505.9 \pm 151.4$ & $3031.6 \pm 151.4$ \\
\end{tabular}

Results represent the average value of two independent analyses \pm uncertainty of measurement (95\%).

phospholipids, which in turn causes cell damage and the consequent increase in the extractability of tocopherols. This fact is well documented but it is not valid for all oilseeds. For instance, for pumpkin seed oil a decrease after heat treatment was observed (Nederal et al., 2012), while safflower shows the same behavior as oyster nut and walnut (Tikekar et al., 2008).

Very interesting and also confirmed by literature data is the possibility to increase the sterol content by heating up the seeds (Siger et al., 2015; Slatnar et al., 2015). Actually, the high
Table 5. Tochopherol composition and content of oil obtained from the two samples of Telfairia pedata seeds.

\begin{tabular}{lll}
\hline Tocopherol & $\begin{array}{l}\text { Oil from } \\
\text { unroasted seed }\end{array}$ & $\begin{array}{l}\text { Oil from } \\
\text { roasted seed }\end{array}$ \\
\hline Alpha, $\mathrm{mg} / \mathrm{kg}$ & 1.5 & 3.0 \\
Beta, $\mathrm{mg} / \mathrm{kg}$ & n.d. & n.d. \\
Gamma, $\mathrm{mg} / \mathrm{kg}$ & 559.6 & 686.2 \\
Delta, $\mathrm{mg} / \mathrm{kg}$ & 4.0 & 5.0 \\
Total tocopherol & $565.1 \pm 26.7$ & $694.2 \pm 26.7$ \\
content, $\mathrm{mg} / \mathrm{kg}$ & & \\
\hline
\end{tabular}

Results (total tochopherol content only) represent the average value of two independent analyses \pm uncertainty of measurement $(95 \%$, for total tocopherol content only).

sterol content of a vegetable oil is regarded as a positive quality, thanks to the ability of phytosterols to compete for absorption with cholesterol at enteric level.

\section{Conclusions}

With this note we are describing in detail the characteristics of Telfairia pedata - oyster seed, in terms of seed and oil composition. The seed is very rich in oil and the yield per hectare very high so one could imagine to invest some money in the industrialization of the culture and on the harvesting of the produced seeds.

The main two fatty acid detected are palmitic and linoleic and the whole fatty acid composition does not show particular properties in comparison with other seed oils.

The cake resulting from oil recovery is rich in good quality properties and in fiber as well. 
Also, an interesting tocopherol content, mainly represented by $\gamma$-tocopherol was found. Also, in the case of oyster nut seed the controlled roasting of the seed allows to recover a higher concentration of sterols and tocopherols into the oil.

Acknowledgements. This paper contains some data kindly produced by INNOVHUB colleagues Anna Cecchetti, Silvia Tagliabue and Pierangela Rovellini who kept in charge the instrumental analyses.

Conflicts of interest. The authors declare that they have no conflicts of interest in relation to this article.

\section{References}

Bondioli P, Folegatti L, Rovellini P. 2020. Oils rich in alpha linolenic acid: chemical composition of perilla (Perilla Frutescens) seed oil. OCL 27: 67. https://doi.org/10.1051/ocl/2020066.

Gao P, Cao Y, Liu R, Jin Q, Wang X. 2019. Phytochemical content, minor-constituent compositions, and antioxidant capacity of screwpressed walnut oil obtained from roasted kernels. Eur J Lipid Sci Technol 121: 100292. https://doi.org/10.1002/ejlt.201800292.

Kanyua NP. 2016. The potential of Telfairia pedata for liquid biofuel and soap production. Thesis submitted in partial fulfillment of the requirements for the Award of the Degree of Master of Science (Chemistry) in the School of Pure and Applied Sciences, Kenyatta University, Nairobi-Kenya (11/2016). Available from https://irlibrary.ku.ac.ke/handle/123456789/15358.

Minzangi K, Mpiana PT, Samvura B, Kaaya AN, Matthäus B, Kadima JN. 2015. Composition of fatty acids and tocopherols content in oilseeds of six wild selected plants from KahuziBiega National Park/DR. Congo. Eur J Med Plants 8(3): 157-166.

Nederal S, Kraljic K, Obranovic M, Papesa S, Bataljaku A. 2012. Chemical composition and oxidative stability of roasted and cold pressed pumpkin seed oils. J Am Oil Chem Soc 89: 1763-1770.

PROTA4U web database. University of Wageningen. Available from www.prota4u.org.

Siger A, Kaczmarek A, Rudzinska M. 2015. Antioxidant activity and phytochemical content of cold-pressed rapeseed oil obtained from roasted seeds. Eur J Lipid Sci Technol 117: 1225-1237.

Slatnar A, Mikulic-Petkovsek M, Stampar F, Veberic R. 2015. Identification and quantification of phenolic compounds in kernels, oil and bagasse pellets of common walnut (Juglans regia L.). Food Res Int 67: 255-263.

Tikekar RV, Ludescher RD, Karwe MV. 2008. Processing stability of squalene in amaranth and antioxidant potential of amaranth extract. J Agric Food Chem 56: 10675-10678.

Cite this article as: Bondioli P, Folegatti L, Morini G. 2021. The chemical composition of oyster nut (Telfairia pedata) seeds and oil. OCL 28: 1. 